\title{
PROPERTIES OF THE AGGLOMERATE AND RE-GRANULATE OF MULTICOMPONENT AND MULTILAYER FOIL WASTE
}

Department of Materials Engineering, West Pomeranian University of Technology, Szczecin, Poland

\begin{abstract}
About $70 \%$ of all materials used in the packaging industry are multicomponent and multilayer foils. Packaging foils are produced with using polymers and aluminum thin foils. Favorable physical and mechanical properties of materials, including higher barrier protection, are the basic factors in the chemical industry. The resulting post-use and post-production foil waste creates serious problem with theirs recycling. In the present paper comparison of some practice collections obtained in the agglomeration and grinding processes are presented. Additionally, changes in physical and mechanical parameters of tested materials were analyzed. Experimental investigations revealed, that the materials obtained in the agglomeration process were better homogenized and possessed improved technical properties.
\end{abstract}

Key words: recycling, grinding, agglomeration, waste packaging foils, multicomponent, multilayer.

\section{INTRODUCTION}

The packaging foils have applications in the various areas of food industry. These follies are used to guarantee the protection of the product, have printed inscription informing the consumer about the content of the finished article and additional sign on the material, which determines the way of the recycling process (Czerniawski et al. 1970). The foils are mainly used as disposable plastic packaging therefore exist trends focused on conversion follies into a by-product by means of the recycling process in the aim of natural environment protection. The main basic material used to produce of the packaging foils is pure polypropylene and politeraphtalen (PET). These polymers are usually used as the composite material in the form of the thin layer heaving thickness ranging between $0.01 \mathrm{~mm}$ and $0.1 \mathrm{~mm}$ (Wilczyński 2011). Additionally, polymers are improved by metalized, or covered by a thermo-welded lacquer and barrier protected layer. The thickness barriers range between $0.01 \mathrm{~mm}$ and 0.03 $\mathrm{mm}$ by means of metalized and aluminum foil (Pielichowski et al. 2003; Raport roczny 2016). To produce packing there are also BOPET pliable foils applied. BOPET is oriented in two directions, laminated and produced by the extrusion process (Hyla 2000). The lamination process enables addition of the metalized layers. These foils obtained in the extrusion process improve the adhesion properties. The metallic layers are often substituted by the metalize layers (Saechtling 2000).

Corresponding author: Przemysław Pruss, Department of Materials Engineering, West Pomeranian University of Technology, Szczecin, Piastów 19, 70-310 Szczecin, Poland, e-mail: przemyslaw.pruss@zut.edu.pl 
The multi-components foils often have the small bulk-density. This state is disturbing the recycling process of multi-layer and multi-components packaging waste (Kozłowski 1998). The post-use and post-production foils wastes are bio degraded with difficulty and pose a serious problem for the protection of natural environment (Grabacz et al. 2012).

In the present paper the experimental investigations have been provided to evaluate the role of different kind of methods and apparatus applied for grinding process. The main aim of the current study was to assess applying for the grinding process of the foils wastes electric mill applied in the corn industry with vertical blades as knifes and the sieve mesh $6-8 \mathrm{~mm}$. The height rotation agglomerator heaving driving motor of $2.2 \mathrm{~kW}$ was also used. It has been shown that the agglomerator may be successfully applied for conversion of waste follies and product providing better homogenization and correct properties of final product than the re-granulates.

\section{MATERIAL AND METHODS}

In our experimental investigations the post-production packaging foils were used. The appearance of these waste foils are shown in Fig. 1. The material consists of the multi-layers foil composed of polyethylene and polypropylene as two polymers components additionally with aluminum layer. Components thicknesses ranged between $0.010-0.060 \mathrm{~mm}$ for polymers and between $0.010-0.020 \mathrm{~mm}$ for aluminum. The density of multi-components waste was $1.7 \mathrm{gm}^{-3}$. The aluminum layer in the multi-component foil has the participation in total mass of the waste ranging from $32 \%$ to $43 \%$. The aluminum layer was used to reinforce the multicomponent foil.

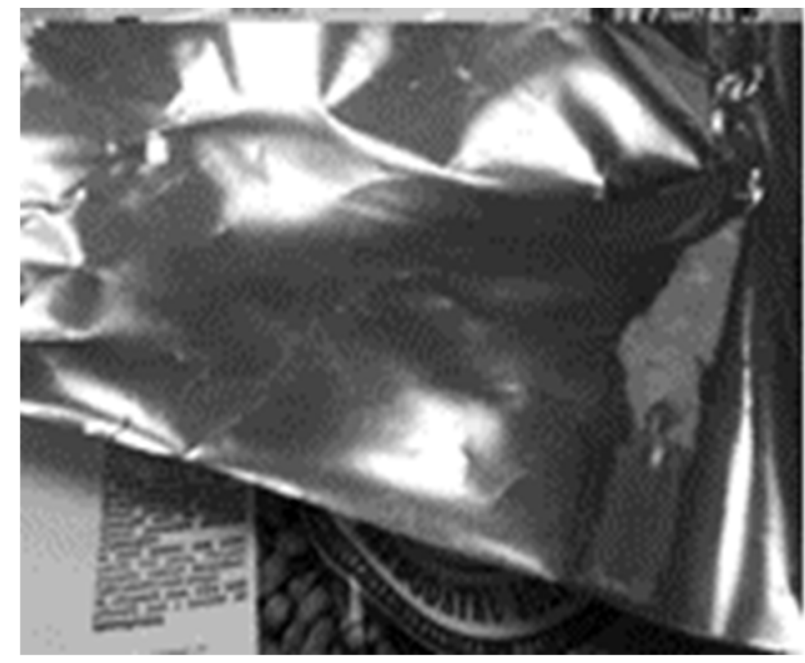

Fig. 1. View of different shape of post-production plastic waste

The post-produce packaging foils are better converted when the waste is especially prepared. It is demonstrated by the fact, that the polymer waste in row state has lower bulk-density, large of specific surface volume (Czaja 2005; Economics and Statistics 2016).

These parameters impede the grinding process. The increasing of bulk-density may be achieved by means of agglomeration process. In this process the polymer wastes were grindined down so that the small fraction of particles were obtained. The material after grinding process was submitted to the agglomerator. The hight temperature as the results of outer heating and additionally heat from the internal friction between material and knifes facilitated the connection of particles. Subsequently, the large pieces of the material were fragmented into the small particles. The experiments have been carried out with using the laboratory agglomerator with driving motor $2.2 \mathrm{~kW}$, cylindrical shape chamber for mass loading of $1500 \mathrm{~g}$, heating source for initial heating of the tested material and horizontal knifes rotation $5400 \mathrm{rpm}$. Material after agglomeration process achieved bulk-density value 
of $12,160 \mathrm{~kg} / \mathrm{m}^{3}$. This value was considerably lower for the proper implementation to the recycling process. Therefore, the material was grinded again with using the corm mill equipped with vertical shaft heaving blades in the form of knife and the sieve mesh in the range between $6 \mathrm{~mm}$ and $8 \mathrm{~mm}$. The obtained product consisted small irregular shape foil flakes from sieve analysis mesh 8-2 mm (Fig. 2). The bulk-density of the foil flakes was value $60 \mathrm{~kg} / \mathrm{m}^{3}$ for the sieve fraction mesh $8 \mathrm{~mm}$.

The bulk-density of the small particles collection obtained from sieving analysis mesh of $6 \mathrm{~mm}$ (Fig. 3) increased to $100 \mathrm{~kg} / \mathrm{m}^{3}(67 \%)$.

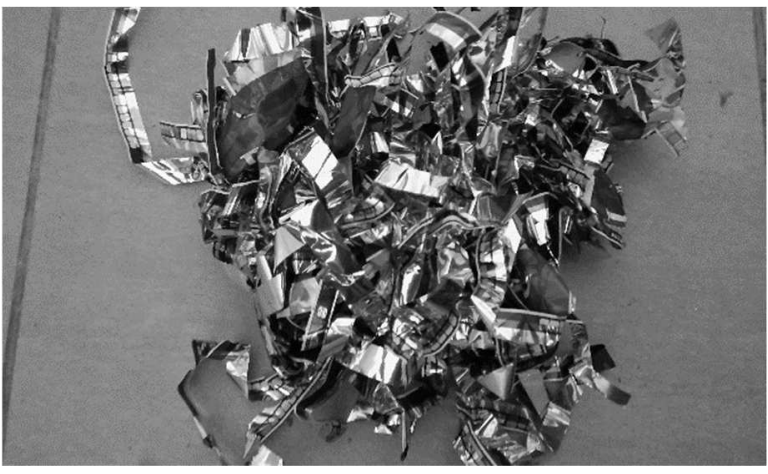

Fig. 2. Research material after the first grinding process using sieve of $8 \mathrm{~mm}$

Finally, the material after agglomeration process was of irregular shape in the form of the heavy coherent camp. The collection of agglomerate particles heaving bulk-density value $200 \mathrm{~kg} / \mathrm{m}^{3}$ is shown in Fig. 4 .

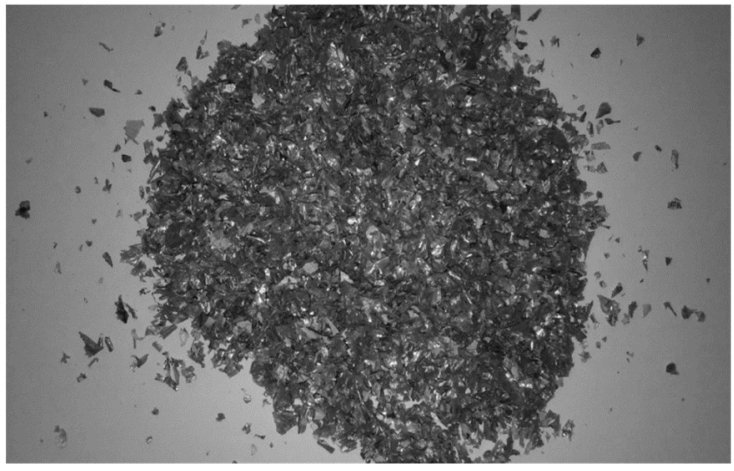

Fig. 3. Research material after the grinding process sieve $6 \mathrm{~mm}$

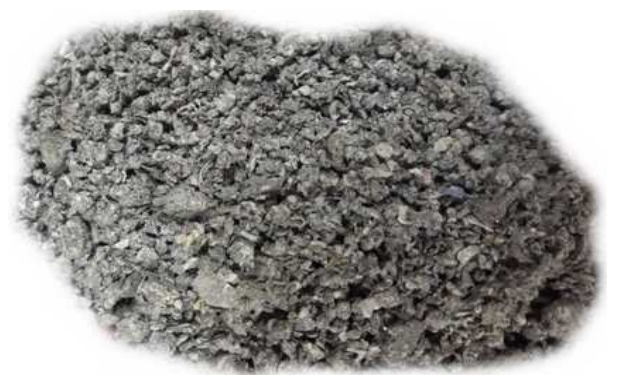

Fig. 4. The obtained agglomerate

\section{RESULTS AND DISSCUSSION}

Material recycling of secondary foils is mainly based on mechanical methods, such as agglomeration or regranulation (Brandrup 1995; Zimniak 2011). This process consists in cleaning the waste material, grinding, melting and re-granulating, without chemical decomposition of the polymer (Polaczek et al. 1998; Zieliński 2003). Material recovery from multi-component waste is the subject of many studies. Among others, the preparation of aluminum foil by thermolysis for use in metallurgy was analyzed (Wojciechowski et al. 2016). Other studies, in turn, describe the problem of managing waste from bubble film by subjecting it to a regranulation process (Rojek et al. 2014).

The investigations have been carried out with using the post-production packaging foils. The main objective of this paper was to demonstrate the effect of the agglomeration process on a grooving value of bulk-density describing the quality of obtained agglomerate. The obtained results revealed the physical and processing characteristics of the agglomerate and re-granulate. In the Figs 4 and 5 the view of two different bulk-density agglomerate collections and their values of the bulk-density are presented, respectively. The value of the 
agglomerate bulk-density was measured by means of a wet method. The A, B, C, D and E shown in Fig. 5 on the horizontal axis demonstrate the bulk-density of the waste foils without initial grinding (A), after agglomeration process (B), after grinding by means of the corn mill with sieve mesh $8 \mathrm{~mm}(C)$, after grinding using of same mill (D) and values of the bulk-density of the granulate as final product of agglomeration process $(E)$.

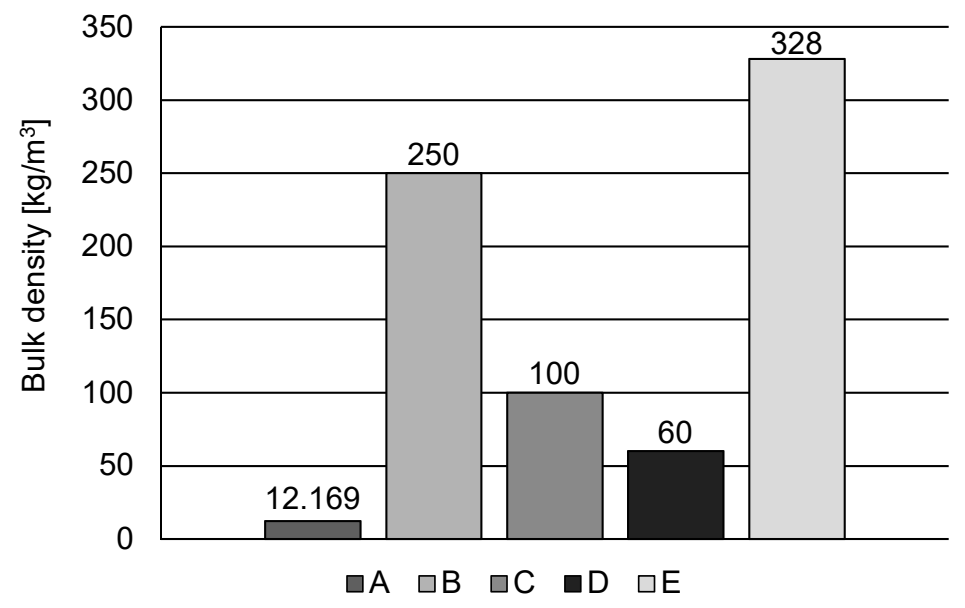

Fig. 5. Bulk density of tested materials A, B, C, D, E

The literature emphasizes the importance of the agglomeration process for obtaining a thermoplastic material of irregular shape and diversified dimensions (Menges 1992). Also carried out research has proved that the decreased values of the bulk-density have a positive effect on properties of waste packaging foils. Obtained materials may be gathered together and then easier introduced in additional innovative technological processes. This is also confirmed by analyzes of various secondary film recycling methods, mainly for the agri-food industry (Zimniak 2011).

The influence of the static load on the mass flow rate was analyzed when temperature reached 200 centigrade. The results are presented in the Fig 6 . It can be seen that agglomerate index Capital MVR ( $\left.\mathrm{cm}^{3} / 10 \mathrm{~min}\right)$ was higher for agglomerates than for re-granulates.

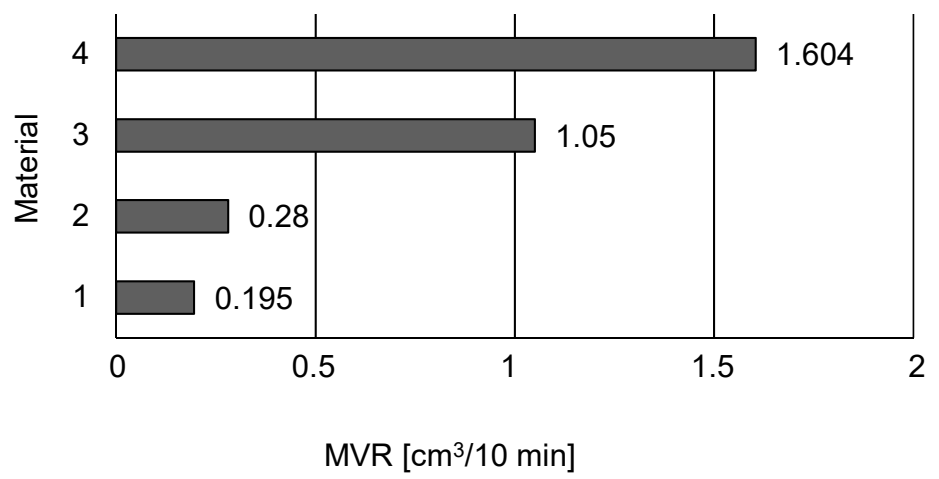

Fig. 6. Melt flow rate tests: 1 - re-granulates $-2.16 \mathrm{~kg}, 2$-agglomerates $-2.16 \mathrm{~kg}, 3-$ re-granulates $-5 \mathrm{~kg}$, 4 - agglomerates $-5 \mathrm{~kg}$ 
The higher of MVR (mass velocity rate) permits an easier reduction of post-produced packaging foils.

The experimental study has been conducted with using the molten agglomerate and re-granulate. It has been shown that temperature and pressure injection had considerable influence on the level filled of a square spiral with the molten material. The results are shown in Fig. 7.

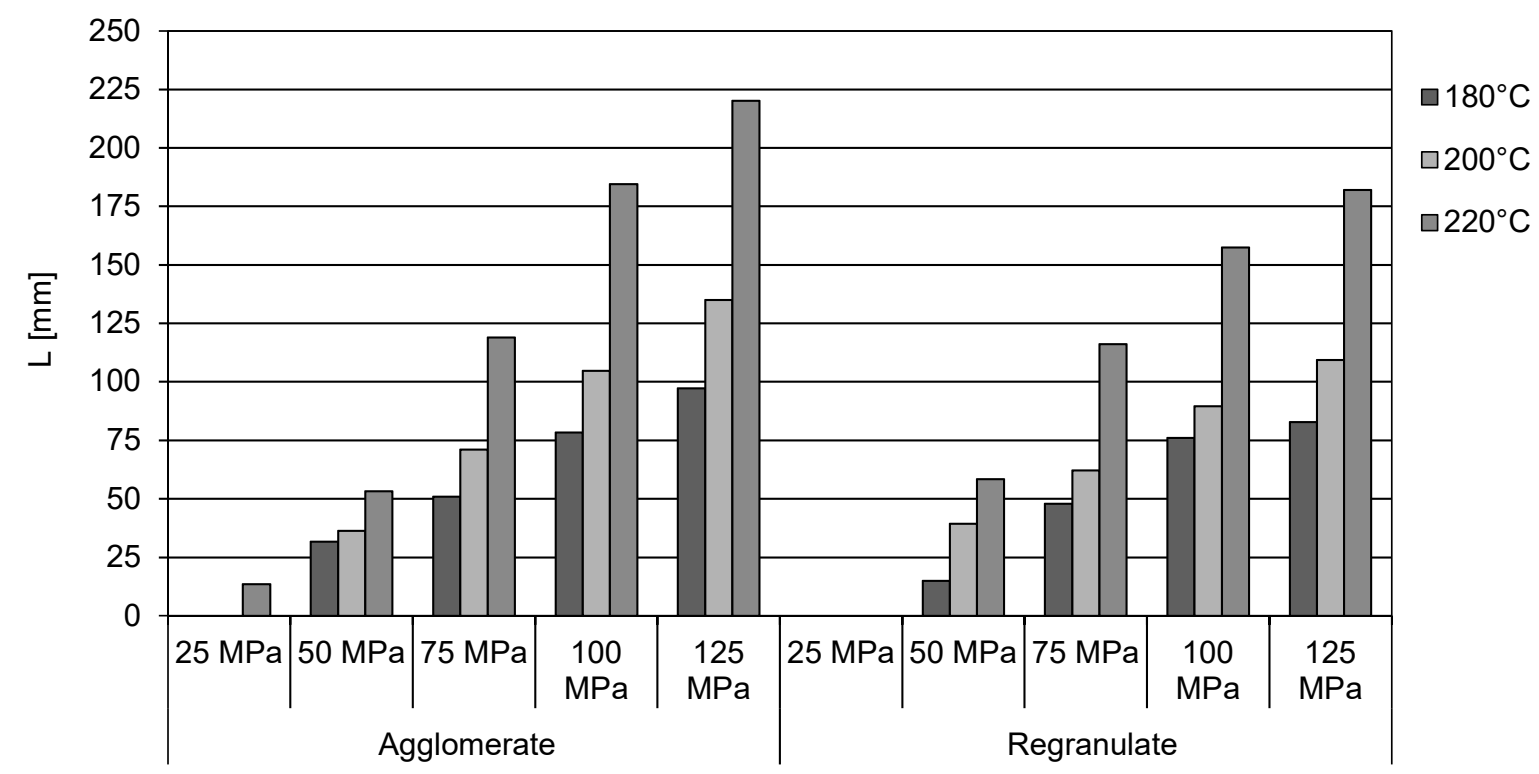

Fig. 7. Influence of temperature and pressure injection on the fill level of a square spiral $L[\mathrm{~mm}]-$ lengthening the sample during a static stretching test

The higher ability to fill form with the molten agglomerate than with re-granulate was demonstrated. This effect was observed when the pressure reached $75 \mathrm{MPa}$.

The previous study determined the influence on the mechanical properties as hardness and impact of two kinds of tested material. These values of five probes for agglomerate and re-granulate are shown in Figs 8 and 9, respectively.

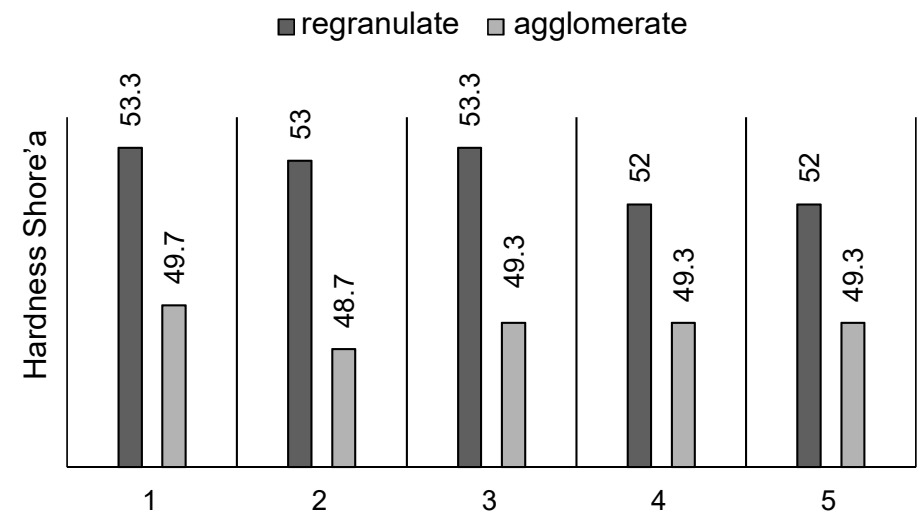

Fig. 8. Values of hardness Shore'a for re-granulate and agglomerate given in five probes 


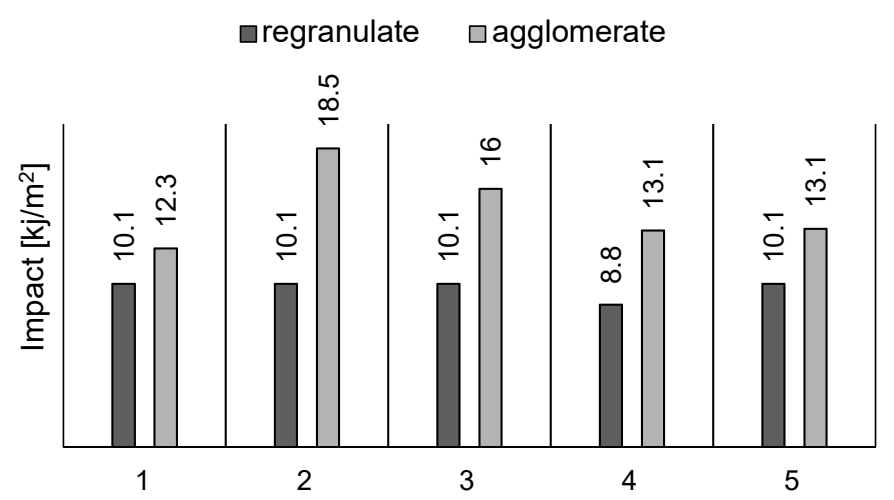

Fig. 9. Values of impact for re-granulate and agglomerate given in five probes

The hardness was determined by means of Shore's type A method. In these experiment precise values of these parameters with using probe of materials in the shape of flat rectangular were obtained. Experimental tests revealed that hardness of re-granulate is somewhat large then obtained with using agglomerate. The mean values $52.5^{\circ} \mathrm{ShA}$ and $49.3^{\circ} \mathrm{ShA}$ were determined for re-granulates and agglomerates, respectively. Comparison of these values revealed, that agglomerate is beneficial for recycling process of post-production packaging foils.

\section{CONCLUSIONS}

1. The agglomeration is an appropriated method to proceed the final recycling process.

2. Final product in the form of granular materials obtained with using mill with blades as knifes and rotor agglomerator or disc agglomerator when used one after the other may be successfully applied for grinding and agglomeration.

3. The granular form of product permits implementation of the another process, facilitating storage and transport.

4. The bulk-density of material obtained in the agglomeration process is smaller then for granulates.

5. Agglomerate is characterized by similar hardness and greater impact then granulates.

6. The grooving thermodynamic parameters, temperature and pressure enhance the ability to fulfill the form.

\section{REFERENCES}

Brandrup J., Bittner M., Michaeli W., Menges G. 1995. Die Wiederverwertung von Kunststoffen. Munchen - Wien, Carl Hanser Verlag. [in German]

Czaja K. 2005. Poliolefiny. Warszawa, WNT. [in Polish]

Czerniawski B., Nasalski A. 1970. Folie opakowaniowe. Warszawa, WNT. [in Polish]

Garbacz T., Sikora J.W. 2012. Przetwórstwo tworzyw polimerowych. Lublin, PLub. [in Polish]

Hyla I. 2000. Tworzywa sztuczne. Własności. Przetwórstwo. Zastosowanie. Gliwice, Wydaw. PŚl. [in Polish]

Kozłowski M. 1998. Podstawy recyklingu tworzyw sztucznych. Wrocław, Wydaw. PWroc. [in Polish] 
Materiały Fundacji Plastics Europe Polska. 2016. Raport roczny, https://www.plasticseurope.org/ /download_file/force/1265/521, access: 20.03.2019. [in Polish]

Menges G., Michaeli W., Bittner M. 1992. Recycling von Kunststoffen. Munchen - Wien, Carl Hanser Verlag. [in German]

Pielichowski J., Puszyński A. 2003. Technologia tworzyw sztucznych. Warszawa, WNT. [in Polish]

Polaczek J., Machowska Z., Wilgosz Z. 1998. Recykling odpadów tworzyw sztucznych przez koksowanie w mieszankach węglowych, w: I Konferencja Naukowa „Recykling tworzyw sztucznych”, Wrocław 25-26.06.1998, [b.m.], Wydaw. PTTŻ, 75-78. [in Polish]

Rojek M., Szymiczek M. 2014. Ocena wpływu dodatku regranulatu na własności opakowaniowej folii pęcherzykowej [Evaluation of the effect of the regranulate additive on the properties of the packaging vesicular film]. Przet. Tworz. 1, 82-87. [in Polish]

Saechtling H. 2000. Tworzywa sztuczne. Poradnik. Warszawa, WNT. [in Polish]

Swift T.K., Moore M., Sanchez E. 2015. Plastics and polymer composites in light vehicles. [b.m.], Economics and Statistics Department, American Chemistry Council. [in English]

Wilczyński K. 2011. Wybrane zagadnienia przetwórstwa tworzyw sztucznych. Warszawa, Oficyna Wydaw. PWarsz. [in Polish]

Wojciechowski A., Pietrzak K., Babul T., Doliński A., Wołosiak M. 2016. Odzysk materiałowy z odpadów wieloskładnikowych metodą termolizy [Material recovery from multicomponent waste by thermolysis]. Inż. Pow. 2, 48-59. [in Polish]

Zieliński T. 2003. Spieniony polistyren modyfikatorem właściwości substancji bitumicznych [Foamed polystyrene as a modifier of the properties of bituminous substances]. Tworz. Szt. Chem. 1, 32-35. [in Polish]

Zimniak J. 2011. Recykling materiałowy folii termoplastycznych stosowanych w przemyśle opakowaniowym i rolno-spożywczym [Material recycling of thermoplastic films used in the packaging and agri-food industries]. Inż. Ap. Chem. 50(3), 95-96. [in Polish]

\title{
WŁAŚCIWOŚCI AGLOMERATÓW I REGRANULATÓW Z ODPADÓW FOLII WIELOMATERIAKOWEJ
}

\begin{abstract}
Streszczenie. W przemyśle opakowaniowym $70 \%$ wszystkich stosowanych materiałów stanowią folie wielomateriałowe. Wśród nich są folie składające się z tworzyw polimerowych oraz metalowych (aluminiowych). Korzystne właściwości tych materiałów, w tym wysoka barierowość powodują duże zainteresowanie nimi w przemyśle. Powstające odpady poużytkowe oraz poprodukcyjne tych folii stwarzają duże problemy $z$ ich recyklingiem. W pracy porównano materiały wytworzone w procesie aglomeracji oraz regranulacji. Analizowano zmiany właściwości fizycznych oraz przetwórczych. Wyniki badań wskazują, że po procesie aglomeracji nastąpiła lepsza homogenizacja materiałów i poprawa ich właściwości.
\end{abstract}

Słowa kluczowe: recykling, folie, rozdrabnianie, aglomeracja, wielomateriały.

We would like to thank Prof. Stanisław Masiuk for critical reading and substantive help with the manuscript. 
